\title{
Aspects Regarding the Role and the Importance of Physical Preparation in the Modern Football Game
}

\section{Cărăbaş Ionică ${ }^{1}$}

\begin{abstract}
In order to achieve the great performance, the physical preparation represents one of the most important factors of the sports training. The development of speed, of force resistance and of skill at superior parameters should represent major objectives in the training of the football teams which aim to attain the top of the national and international hierarchies. The results of the assessments of the football games at high level, confirm this hypothesis that is why the physical preparation should be reconsidered and adapted to the requirements of the modern play. According to the opinion of the great specialists of the field, the physical qualities have a weight of $47 \%$ compared with the other qualities which a top football player should possess. For us the trainers, it is only about to find the most appropriate means in order to develop and exploit at maximum, those qualities.
\end{abstract}

Key words: physical preparation, development, football.

\section{Rezumat}

În atingerea marii performan $\square$ e, pregătirea fizică reprezintă unul dintre cei mai importanți factori ai antrenamentului sportiv. Dezvoltarea vitezei, forței rezistenței şi îndemânării la parametrii superiori trebuie să constituie obiective prioritare în pregătirea echipelor de fotbal care îşi propun să acceadă spre vârful ierarhiilor interne şi internaționale. Rezultatele evaluărilor jocurilor de fotbal la nivel înalt confirmă această ipoteză, motiv pentru care pregătirea fizică trebuie reconsiderată şi adaptată cerințelor jocului modern. Conform opiniei marilor specialişti ai domeniului, calitățile fizice au o pondere de $47 \%$ în raport cu celelalte calități pe care trebuie să le posede un jucător de fotbal de top. Nu ne rămâne, ca antrenori, decât să găsim mijloacele cele mai potrivite pentru a dezvolta şi exploata la maximum aceste calități.

Cuvinte cheie: pregătire fizică, dezvoltare, fotbal.

\footnotetext{
${ }^{1}$ Lecturer PhD, Physical Education and Sport Faculty, West University of Timisoara, email: icarabas@yahoo.com
} 


\section{Introduction}

The physical preparation represents a system (ensemble) of measures to assure a high functional capacity of the body, through the high level of the development of the motility capacities, optimal values of the morpho-functional indices, fully mastering of the used exercises and a state of perfect health.

The physical preparation includes two aspects as follows:

1. The general physical preparation (GPP) which ensures the development of the basic motility capacities and of the functional capacities, enhances the general background of motility abilities and assures the harmonious development of the morpho-functional indices, which conditionate the practising of the sport branch;

2. The specific physical preparation (SPP), which ensures the development of the effort capacity specific to a sport branch, and also of the motrical qualities prioritary combined and differently implied, determining, at last the specific efficiency. [1] (Figure 1)

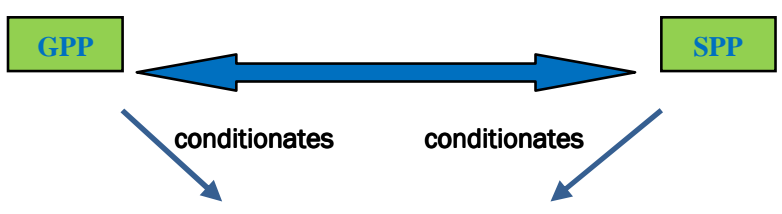

SPORTSMAN EFFICIENCY

Figure 1. the general physical preparation (GPP) and the specific physical preparation (SPP)

The physical effort implies the muscular, energetical, information transmitting and processing system and determines a specific level of body stress which has as an effect the development of the physical, functional-biochemical and mental capacities, at different levels. From the stress point of view, the physical effort can be exhaustive, maximal, undermaximal, medium and small.

The characteristics of the physical effort in football are the following:

a. The long -term competitional calendar which extends on a period of about 9-10 months ;

b. The regularity of the official games (weekly cycles) which lead to rhytmic stress;

c. The variability of the sporting shape which must ensure the maximum efficiency of the team players at the stipulated dates and periods, in perfect correlation with the representatives calendar;

d. The great duration of the playing period, plus the possible prolongations (90' plus 30');

e. The big dimendions of the football pitch (120/90 m) and its quality;

f. The big number of players (of both teams - 22);

g. The performing of the game outdoors irrespective the weather conditions or on a covered football pitch (SUA 1994) with excessive temperature and humidity;

h. On the whole playing period, the activity is performed on total engagement conditions and in a constant rhythm, alternating the compartments and lines of players according to the applied game system;

i. The complex character of the effort in the football play given by the necessity of upkeeping the tempo and of the total engagement till the last second of the game (physical and mental freshness). [2]

\section{Contents}

For a better illustration of the physical factor's weight in the actual football game, it should be reminded that at the final tournament of the World Football Championship in 1954, performed in Switzerland, a player used to cover during a match, a distance of about $4 \mathrm{~km}$, while at the World Championship in 2010, which took place in South 
Africa, the players covered a distance ranged between 8 and $12 \mathrm{~km}$ per match. Depending on the position on which they play, the average distance covered by the top players and the physiological stress in football, is as following (Table I).

Table I. The average distance covered by the top players

\begin{tabular}{lcccccc}
\hline $\begin{array}{l}\text { Average } \\
\text { covered by the position }\end{array}$ & Wistance $(\mathrm{km})$ & Walking & Running 2/4 & $\begin{array}{c}\text { Way of moving } \\
\text { Running 3/4 }\end{array}$ & Sprint & Others \\
\hline A & 9.5 & 2.5 & 4 & 1.25 & 0.8 & 0.95 \\
H & 11 & 2.8 & 5 & 1.5 & 1 & 0.8 \\
D & 8.5 & 2.5 & 3.5 & 1.1 & 0.6 & 0.8
\end{tabular}

Legend: A - Attackers;H - Halfbacks; D - Defender

The percentage of the implied energetical systems in the football game is the following (Table II):

Table II. The percentage of the implied energetically systems in the football game

\begin{tabular}{lll}
\hline $\begin{array}{l}\text { Anaerobic } \\
\text { alactacide }\end{array}$ & $\begin{array}{l}\text { Anaerobic } \\
\text { lactacide }\end{array}$ & Aerobic \\
\hline $15 \%$ & $15 \%$ & $70 \%$ \\
\hline
\end{tabular}

From the prevailing energetic system point of view, on positions, we can conclude that (Table III):

Table III. Energetic system point of view, on positions

\begin{tabular}{lccc}
\hline Position & $\begin{array}{c}\text { Anaerobic } \\
\text { alactacide }\end{array}$ & $\begin{array}{c}\text { Anaerobic } \\
\text { lactacide }\end{array}$ & Aerobic \\
\hline Goalkeeper & $\mathrm{X}$ & $\mathrm{X}$ & \\
Defender & $\mathrm{X}$ & $\mathrm{X}$ & $\mathrm{X}$ \\
Halfback & & $\mathrm{X}$ & $\mathrm{X}$ \\
Atacker & $\mathrm{X}$ & \\
\hline
\end{tabular}

The distance between 8 and $12 \mathrm{~km}$ are covered by the players during the matches, as follows (Figure 2):

- walking - $2.6 \mathrm{~km}$, with a speed of $3.6 \mathrm{~km} / \mathrm{h}$;

- running in a moderate tempo - $3.3 \mathrm{~km}$, with a speed ranged between 8 and $14 \mathrm{~km} / \mathrm{h}$;

- speed running - $1.2 \mathrm{~km}$, with a speed ranged between 15 and $25 \mathrm{~km} / \mathrm{h}$;

- maximal speed - $750 \mathrm{~m}$, with a speed ranged between 26 and 32 km/h;

- running backwards the direction -350m.

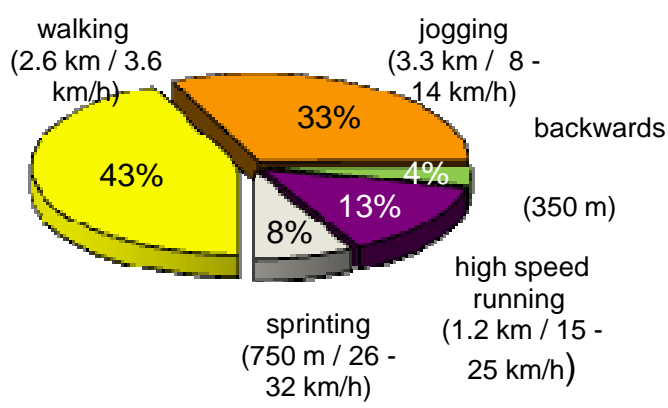

Figure 2. The distance between 8 and $12 \mathrm{~km}$ are covered by the players during the matches

It results that a big part of the effort performed by the football players takes place in the form of jogging, where from the necessity of the development of the aerobic capacity, base of making long term efforts capacity and of possibilities of rapid recovering after the effort. .

The modern football implies, at the senior level, somewhere around 60 - 70 matches on season, many of them decided on the final of the game, at which if we add the long distances for covering during the moving, we obtain a clear picture of the necessity for aerobic capacity development at the parameters imposed by the great performance.

It is to be mentioned that the semiprofessional players cover during a match, about the same distance, the difference being in the speed of the running and its quality. 
The last years have brought a significant increase in the volume of the runnings of great intensity, from values ranged between $8-12 \%$, to values ranged between $24-28 \%$, from the total covered distance . (Figure 3)
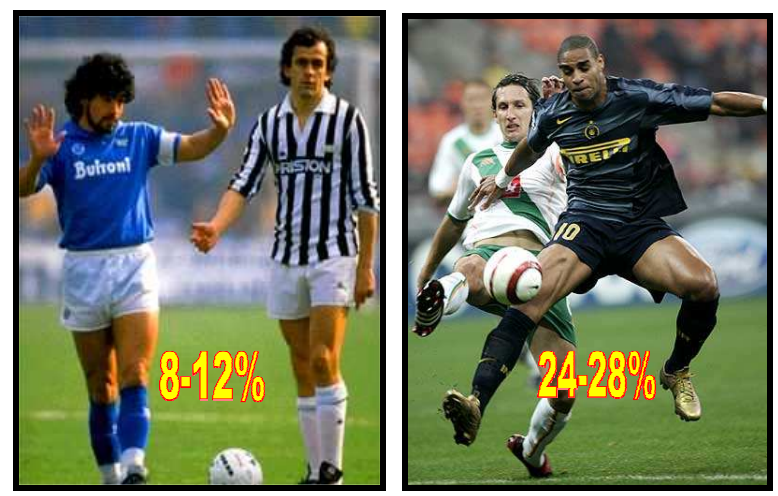

Figure 3. The volume of the running of great intensity [6]

Since 1996, one of the most famous technicians, Valeri Lobanovsky, said: "the players should react faster. Each action takes place with an increased rapidity. React faster, play faster - this is the future of football." The actual football totally confirms the hypothesis of the great technician.

The sprints with the ball at the foot reach at present at an amount of $160-300 \mathrm{~m}$, which represents between 1.7-3.1\% from the distance covered during a match. The moving speed developed in this form has attained values difficult to imagine. For example, the Portuguese player, Cristiano Ronaldo develops with the ball at foot, a speed of $33.6 \mathrm{~km} / \mathrm{h}$, a value very closet o that developed by the fastest man of the planet Usain Bolt on the distance of $200 \mathrm{~m}$ flat $37.15 \mathrm{~km} / \mathrm{h}$. (Figure 4)
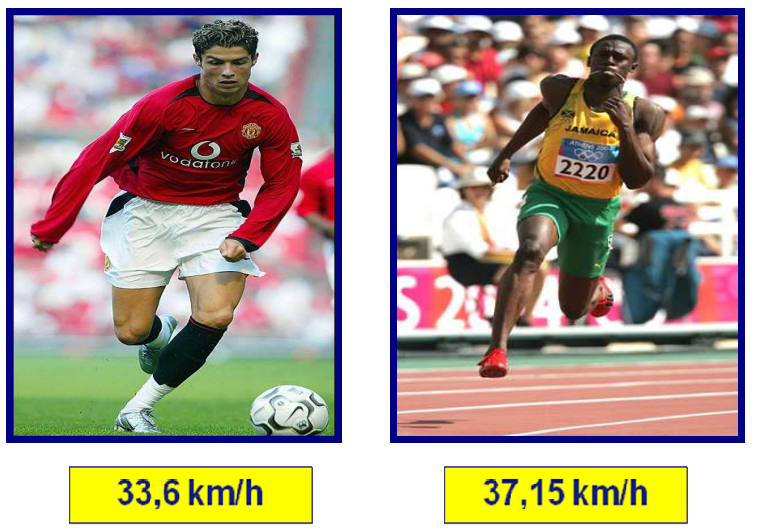

Figure 4. Speed developed by C. Ronaldo [7] and U. Bolt [8]

In order to comply to the requirements of the actual football, the players must develop a speed which should allow them the covering of a distance of $5 \mathrm{~m}$ in less than a second and of the distance of $30 \mathrm{~m}$ in less than $4 \mathrm{sec}$.

The accelerating in a very short time capacity ultimately makes the difference, the game implying during ita course no fewer than 1100 changes of intensity. The researches show that at every $40-45$ sec. there an increased intensity effort.

Those mentioned above are supported also by the cardiac frequency during a football match graphs, shown in figure 5 , which indicates the fact that the cardiac frequency is situated on a period of $28 \mathrm{~min}$. at 85 - 90\% from the maximum CF, 19 min. at 90 95\% from maximum $\mathrm{CF}$ and $9 \mathrm{~min}$. at $95-100 \%$ from maximum FC. In other words, 2/3 from the game CF is situated at values above $85 \%$ from the maximum CF, so the effort is an intense one. [3] 


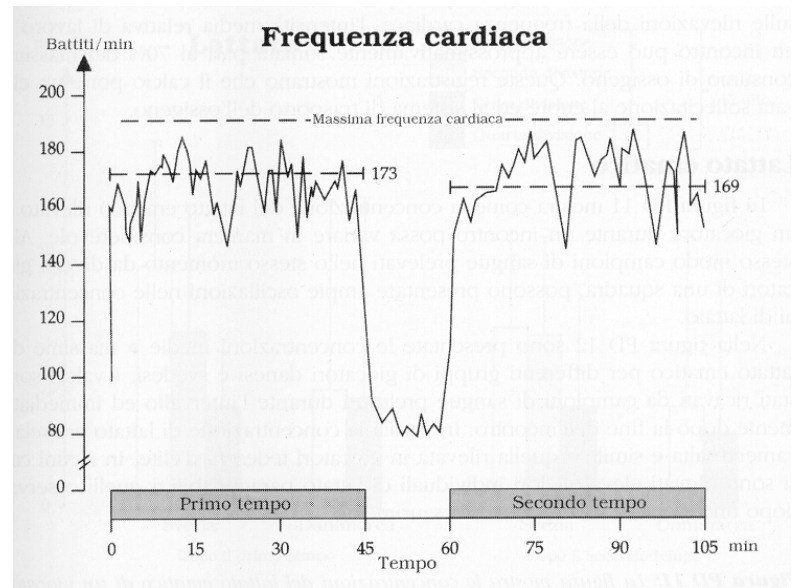

Figure 5. Cardiac frequency during a football match. [5]

Another characteristic of the modern football game is represented by the force, figure 6 showing the continual increasing of the number of the game duels during the last two decades. We cannot talk about an efficient expression in regime of adversity, without a corresponding force, under its all forms of manifestation [4].

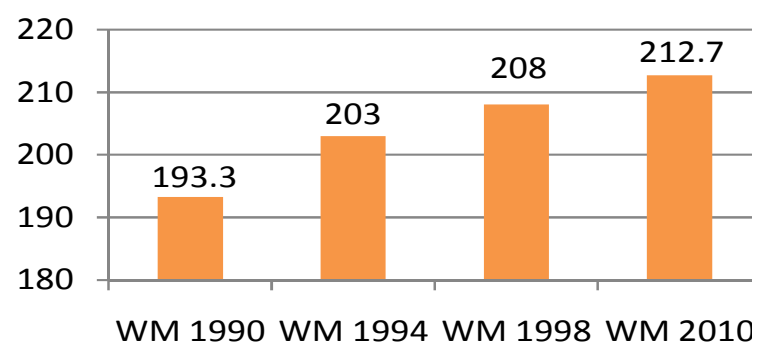

Figure 6. The number of the game duels during the last WM

The improving of the coordination and of the individual technique represent also desideratum without which we cannot cope with the rigours imposed by the actual football. The constraints determined by the constant increasing density of players on the different zones of the football pitch and of the greater and greater playing speed, impose a coordination and a technical expression of a perfect accuracy.

\section{Conclusions}

We can conclude that football is a sport which, from physical point of view implies intense actions, performed on a relatively long period of time, in a permanent adversity regime, which leads to the necessity of training the sportsman in order to cope to those requirements through:

- extraordinary aerobic capacity;

- force/strength;

- elasticity / explosion in segments;

- extraordinary speed;

- rapid comeback after intense and repeated actions.

The trainings should be such structured and conceived as to contribute to:

- increasing of the aerobic capacity for the improving of recovering ;

- development of the maximum aerobic power;

- training on intervals- intermittently training ;

- improving of spring (force and speed);

- coordination/technique improving.

\section{References}

1. Bompa T.O. (2001) Teoria şi metodologia antrenamentului sportiv. C.N.F.P.A. Bucureşti;

2. Hoff J. (2005) Training and testing physical capacities for elite soccer players. Journal of Sports Sciences, 23(6): 573 - 582;

3. Achten J., Jeukendrup A.E. (2003) Heart rate monitoring: Applications and limitations. Sports Medicine, 33, 517 - 538;

4. Wisloff U., Helgerud J., Hoff J. (1998) Strength and endurance of elite soccer players. Medicine and Science in Sports and Exercise, 30, 462 - 467.

5. Bagsbo J. (2003) Fitness training in soccer - a scientific approach. Reedswain Publishing, Michigan, pg. 71.
6. http://ilrigorista.blogspot.ro
7. http://www.realitatea.net/tag/cristiano ronaldo
8. http://usainbolt.com 